\title{
2007년 IPPF 공여국 협의회 결과 보고
}

2007년 IPPF 공여국 협의회가 KOICA, CIDA, SIDA, DFID, JICA, UNFPA, 일본 외무성, 덴마 크 외무부 등 각국 정부, 원조 기구 및 국제기구의 참석하에 국제인구보건복지연맹 (IPPF: International Planned Parenthood Federation) 주최로 1.25 26일 양일간 영국 런던에서 개최되 었음. (대표단 : KOICA 정책연구실 김영경 직원, 인구보건복지협회 윤영옥 팀장)

\section{1. 종합 관찰 및 평가}

- 동 회의를 통해 성생식보건권리(SRHR : Sexual Reproductive Health and Rights)는 좌시되어서는 안될 인간의 기본적인 권리 중 하나이며, SRHR 보장이야 말로 개도국의 빈 곤 퇴치 및 개발문제 해결 등 MDGs 달성에 중요한 요소임을 재확인함.
- 아울러, IPPF가 우선순위를 두고 있는 5A(1) safe abortion (2) HIV/AIDS (3) Access (4) Adolescents (5) Advocacy)와 관련하여, 혁신 적인 사업 성과 및 과정에 대한 보고를 받음.

- SRHR 헌장을 2008년까지 법안으로 발전시 키기 위한 IPPF 내부 의견 조율 작업이 진행 중이며,

- 아프리카 지역의 성생식보건 문제를 자체적 으로 개선해 동 지역의 MDGs 달성을 꾀하 자는 마푸토(Maputo)회의가 개최된 바 있 고,

- 사업의 평가 및 모니터링을 강화하기 위해 자체 개발한 지표인 Global Indicator를 지 속적으로 다듬고 있음.

- 이에 원조 공여국들은 꾸준히 지원 금액을 늘 려 2006년에는 IPPF 역사상 최고치를 기록한 바, 이는 원조 공여국들이 IPPF의 혁신적 노 
력에 대한 평가와 신뢰를 반영한 것으로 평가 됨. 우리나라 역시 2005년 쓰나미 펀드(50만 미불)에 이어 2007 8년 한-아프리카 펀드 (100만 미불) 지원을 공약하였음.

- 보건분야는 KOICA의 주요 사업분야로 '05년 총 예산 중 약 $23 \%$ 를 차지했지만, 성생식보건 분야는 $0.27 \%$ (재난복구로 분류된 ' 05 년도 쓰 나미펀드 포함)에 불과한 바, 동 분야에서 한 국의 Visibility를 부각시키면서도 사업 집행 의 효과성을 높이기 위해서는 성생식보건 전 문 국제 $\mathrm{NGO}$ 인 IPPF 혹은 UNFPA와의 협력 을 강화할 필요가 있다고 사료됨.

- 아울러 "공여기관과의 대화" 시간에 한국 및 일본 대표는 IPPF가 세계 성생식보건 분야 전 문 $\mathrm{NGO}$ 이자 $\mathrm{UN}$ 자문기관인 점을 감안, 공여 국의 공통적 문제인 고령화 문제에 대한 IPPF 의 관심을 요청함.

2. IPPF 공여국 회의 ('07.1.25) : IPPF Annual Consultive Meeting with Donors

\section{가. Jacqueline Sharpe IPPF 회장의 환영사}

: IPPF 신임 사무총장 Dr. Gill Greer 약력 소개, $\mathrm{IPPF}$ 의 인가 절차, 전략적 프레임워크 $(5 \mathrm{~A})$, 성 생식보건 법안

- 07 년도 공여국 회의 참석자들에게 환영사를
전하면서, 특히 동 회의에 처음 참석한 한국, 아일랜드, 이태리, 스페인 대표단에게 사의를 표명함.

- Mr. Steven Sinding의 후임인 Ms Gill Greer 신임 IPPF 사무총장은 SRHR 분야의 전문가이며 뉴질랜드 APA(Aisa Pacific Alliance), 뉴질랜드 NGO 보건복지부 포럼의 회장 직을 두루 역임한 바 있음.

- 2006년 마케도니아(구 유고슬라비아)와 쿡 아 일랜드가 IPPF 협회(Member Association)로 가입했으며, 레바논은 IPPF 협회 권고사항을 준수하지 못한 관계로 협회에서 제외되었음. 동 인가(Accreditation) 절차는 강화된 모니터 링과 평가 시스템으로 사업 집행의 효과성을 도모하기 위한 것임.

- IPPF는 세계에서 2 번째로 큰 규모의 $\mathrm{NGO}$ 이 며, 각 협회의 grass roots에 기반을 둔 접근 법을 통해 IPPF의 전략적 프레임워크( $5 \mathrm{~A}-$ - (1) safe abortion (2) HIV/AIDS (3) Access (4) Adolescents (5) Advocacy)를 수행하고 있음. $5 \mathrm{~A}$ 는 ICPD(International Conference on Population and Development, 1994. 카이 로) 비전과 MDGs 달성을 위해 긴요함.

- IPPF의 성생식보건권리 헌장(Charter of Sexual Reproductive Health and Rights) 
및 전략적 프레임워크에서 성 권리(Sexual Rights)는 인간의 기본적 권리 중 하나로서 삶 을 완성시키는 부분으로 강조됨. 그럼에도 불 구하고 동 권리는 쉽게 좌시되어 왔는바 이는 모성사망 증가, HIV/AIDS 확대와 같은 비극 적 결과를 초래했음.

\section{나. Gill Greer 사무총장의 인사말}

: MDGs 타겟에 성생식보건 포함, 미푸토 회의아프리카 행동계획 수립, 한-아프리카 펀드, Global Indicators

- SRHR 분야는 2006년에 혁혁한 발전을 이루 었음. (1) MDGs 타겟 변화 (2) 아프리카 행동 계획 (Maputo) 수립 (3) 한-아프리카 펀드 설 립 (4) Global Indicators 등의 성과를 들 수 있음.

- IPPF는 시민사회단체 및 각국 정부와 협력하 여 SRHR가 개발의 초석이라 할 수 있는 여성 의 권리신장 및 빈곤퇴치에 크게 기여하는 바, 9번째 MDGs가 되어야 한다고 주장했음. 2005년 기념비적인 World Summit Outcome Document에서는 SRHR가 MDGs 달성에 중요하다고 인정했으며, 2006년 UN 총회에서는 '2015년까지 생식보건에 대한 전 반적인 접근성 (universal target to reproductive health by 2015)을 높여야 한다 는 추가 MDGs 타겟을 설정한 바 있음.
- IPPF는 최근 한국과 "한-아프리카 펀드" 협 정서를 체결하였음. $\mathrm{KOICA}$ 의 대 IPPF 지원 금 총 100만 미불은 2007 8년간 3개 아프 리카 최빈국(우간다, 레소토, 부르키나 파소) 의 성생식보건 개선을 위해 쓰여질 것임. 앞 으로 한국과 $\mathrm{IPPF}$ 의 협력 관계가 강화되기 를 기원함.

- $\mathrm{IPPF}$ 는 자체 성과의 포괄적 모니터링 및 평가 를 위해 Global indicator를 다듬고 있음. 전 자 정보 시스템을 통한 서비스 데이터 수립을 위해 오랜 작업을 해왔고, 앞으로도 동 지표가 정보수집, 분석, 피드백 제공에 도움이 될 수 있도록 노력을 경주할 것임.

\section{다. 재정보고 (2005년)}

- IPPF 협회의 총 수입 264.4 백만 미 달러 중 $63 \%$ 는 지역수입, $21 \%$ 는 IPPF를 통한 지원 금, $16 \%$ 는 국제기구를 통한 지원금임.

- IPPF 사무국을 통한 수입 92.9 백만 미 달러 중 $80 \%$ 는 Unrestricted 자금, $20 \%$ 는 Restricted 자금임

※ Restricted Fund-특정 목적을 위해서만 쓰 이는 자금으로, '05년 외교통상부의 쓰나미 펀드, '07 08년 KOICA의 한-아프리카 펀 드의 경우 Restricted 자금임. 
※보건복지부의 연간 자발적 지원금은 Unrestricted 자금에 속함.

- 2005년 Unresticted 최대 공여국은 일본 (20\%), 영국(17\%), 스웨덴(16\%), 덴마크(10\%), 노르웨이(9\%), 네덜란드(8\%), 캐나다(5\%), 독 일(5\%), 호주(2\%), 기타(7\%)이고, 2006년 Unrestricted 최대 공여국은 스웨덴(19\%), 영 국(19\%), 일본(17\%), 덴마크(10\%), 노르웨이 (9\%), 네덜란드(7\%), 캐나다(6\%), 독일(5\%), 호주(2\%), 기타(6\%)임.

- $\mathrm{KPMG}$ 외부 감사는 2005년 IPPF의 재무제 표에 적정의견을 제출함.

\section{라. IPPF의 Global Indicators}

- Global indicator는 IPPF 협회에서 실시하는 사업의 모니터링 및 평가를 위한 것으로, 협회 는 매년 global survey (22개 지표)와 온라인 통계 모듈(8개 지표)을 제출함.

- 2005년, 84\%에 달하는 협회가 global survey를 제출했고 그 중 $63 \%$ 에 달하는 협 회가 서비스 통계 모듈을 제출했음.

- 2005년 주요 결과

- 총 30.7 백만 명이 성생식보건 서비스를 제 공받았음.

- 그 중 17.3 백만 명이 피임 서비스를 제공 받
았고,

- 13.4 백만 명이 기타 성생식보건 서비스*를 제공 받았음.

(*산부인과, 모자 보건, HIV/AIDS, 낙태, 불 임, 성병)

- 총 30.7 백만 명 중 7.9 백만 명(약 26\%)은 젊 은이였음.

- $17 \%$ 의 협회는 중앙이사회에 최소한 $20 \%$ 의 젊은이를 포함하고 있음.

- 68\%의 협회는 IPPF의 의학서비스 가이드라 인에 따라 질적관리 보장 시스템을 갖추고 있음.

- 협회는 성생식보건 분야에 있어서 51 여개의 성공적인 국가 정책 및 법안의 변화를 이끌 어냈음.

- 앙골라 IPPF 협회는 자국의 성생식보건 정 책의 수정 및 HIV/AIDS 관련법 마련에 큰 역할을 수행했음.

- 라트비아 IPPF 협회는 자국의 강력한 캠페 인 운동을 통해 낙태금지법안을 철폐시켰음.

- 체코, 캐나다, 멕시코의 IPPF 협회는, 캠페 인을 통해 각국의 응급 피임 사용이 확대되 었음.

\section{마. From Charter to a Bill :} 성생식보건 헌장에서 법안까지

- SRHR 법 안 은 IPPF WHR(Western Hemisphere Region)에서 시작되었으며 2008 
년 까지 IPPF 협회 내에서 의견 조율을 거쳐 합 의를 보고자 함.

- 1994년 카이로 ICPD와 1995년 베이징 회의 에서 SRHR은 인간의 기본 권리인 점을 명시 한 바 있음. 하지만 종교적 원리주의와 문화적 터부로 인해 일부 국가, 지역에서 SRHR는 언 급조차 하기 힘든 문제임.

- 따라서 동 법안의 취지는 SRHR가 인권 문제 인 점을 강조하여 성적 취향 및 성별의 이유로 신체, 정보, 교육, 보건상의 차별을 받지 않도 록 분명히 하고, IPPF 내 여러 지역 협회의 중 지를 모아 혁신적이고 창의적인 해결책을 찾 기 위한 것임.

\section{바. Maputo plan of action :} 아프리카의 행동계획

- 2006년 9월 모잠비크의 수도 마푸토 (Maputo)에서는 $\mathrm{AU}$ 회원국의 보건복지부 장 관들이 모여 아프리카의 모성, 유아, 아동 사 망률을 줄이고 $\mathrm{HIV} / \mathrm{AIDS}$ 를 퇴치해 동 지역 에서의 빈곤을 감소시키자는 "행동계획 (Action of Plan)"을 채택했음.

- 계획의 요지는 SRHR 서비스를 1차 의료 서비 스로 통합시키자는 것임.
- 현재 아프리카 대륙의 모성 사망은 약 20명 중 한명으로 세계 어느 지역보다 높으며, 이는 세계 전체 모성 사망의 $50 \%$ 에 달함.

- 마푸토 회의는 아프리카 국가 스스로 동 지역 의 SRHR를 위한 진취적 행동계획 수립에 합 의했다는데 의의가 있음.

\section{사. 공여국의 피드백}

- KOICA

- SRHR와 IPPF의 성과를 배우는 귀중한 자 리였음.

- 한국은 신흥 공여국으로서 아직 ODA 절대 적 규모가 크진 않지만, $\mathrm{OECD} / \mathrm{DAC}$ 가입 및 아프리카 지역의 MDGs 달성을 위해 노력을 경주하고 있는 바 그 규모는 커질 것으로 예 상됨.

- 이번 한-아프리카 기금으로 인해 한국과 $\mathrm{IPPF}$ 의 협력관계가 강화되기를 기대하며,

- IPPF가 세계 성생식보건 분야 전문 $\mathrm{NGO}$ 이 자 UN 자문기관인 점을 감안, 공여국의 공 통적 문제인 고령화 문제에 대한 $\mathrm{IPPF}$ 의 관 심을 요청함.

- 일본

- 07 년 IPPF 공여국 협회의 개최를 축하드리 며 IPPF의 grass roots를 통한 여러 활동을 높이 평가하는 바임. 
- 최근 일본은 JTF(Japan Trust Fund) 기자 단을 이디오피아에 초청해 IPPF 와의 사업 을 소개한바 있고, 이는 IPPF와의 협력사업 을 홍보하는 모범사례로 손꼽힘.

- 일본의 고령화 상황을 설명하면서 IPPF의 $\mathrm{SRHR}$ 법안이 고령화를 포함한 생애 주기의 성적 이슈를 다루어 주기를 희망함.

- 2007년 지원 규모는 작년과 동일하나, 엔화 로 지급되는 까닭에 환율로 인한 약간의 하 락이 예상됨.

- SIDA

- 최근 SIDA는 성생식보건 분야의 정책을 수 립한 바 있음. $\mathrm{SIDA} / \mathrm{NORAD}$ 는 IPPF의 빈 곤감소 활동을 긍정적으로 평가함.

- 모든 IPPF 협회의 활동은 권리에 기반 해야 하고 동시에 각국의 특수 상황에 맞는 빈곤 감소 전략이 마련되어야 할 것임.

- NORAD

- NORAD는 IPPF를 비롯한 국제 NGO에서 제출한 자금 지원안을 검토하고 있음. 2007 년 대 IPPF 지원 규모는 작년과 비슷할 것으 로 예상됨.

- 핀란드

- IPPF는 핀란드의 오랜 협력기관이며 앞으로 도 중요한 파트너로 남을 것임. 핀란드의 2007년 대 IPPF 지원 규모는 증가될 것으로 보임.
- UNAIDS

- UNAIDS는 앞으로 에이즈 예방 활동에 더 주력할 것임. $\mathrm{IPPF}$ 가 에이즈 환자들에 대한 사회적 낙인을 철폐하는 등 권리에 기반을 둔 활동(rights-based approach)을 하고 있 어 매우 고무적임.

- 독일

- 독일 정부는 IPPF의 성과를 긍정적으로 평 가하고 있으며 UNFPA(United Nations Population Fund, 유엔인구기금)와의 협력 관계와 마찬가지로 $\mathrm{IPPF}$ 와의 협력관계에도 큰 의미를 부여하고 있음.

- 스위스

- SRHR 법안 및 안전한 낙태를 위한 법안 마 련 등 IPPF의 혁신적 시도를 높이 평가함.

a 패커드 파운데이션

- 패커드 파운데이션은 아프리카(나이지리아, 탄자니아)의 애드보커시 활동을 강화하기 위 해 IPPF 에 신규 펀드를 제공했음.

- DFID

- IPPF가 시민사회조직으로서의 중요하고 독 특한 역할을 하고 있다고 평가함. IPPF가 $\mathrm{UNAIDS}$ 및 UNFPA와 같은 UN기관과의 협력관계를 구축하는 것에 대해 긍정적으로 생각함.

- 특히 마푸토 회의에서의 애드보커시 활동은 
매우 고무적임.

- DFID의 2007년 대 IPPF 지원 규모는 7.7 백만 파운드가 될 것이며 $\mathrm{IPPF}$ 와 다년간 펀 딩계약을 기체결한 바 있음.

\section{SRHR와 빈곤에 대한 특별세션( '07.1.26)}

: Special Session on Poverty and Sexual \& Reproductive Health and Rights

- SRHR는 다른 사업에 의해 쉽게 우선순위에 서 밀리는 경향이 있음. 이는 의사결정권자를 포함한 일반인들이 SRHR와 빈곤의 상관관계 를 쉽게 납득하지 못하기 때문임.

- 빈곤은 소득, 능력 등 여러 가지를 기준으로 정의를 내릴 수 있으며 대부분 한 가구의 소득 이 하루 2 달러 미만일 경우 빈곤층, 1 달러 미 만일 경우 절대빈곤층으로 분류함. 하지만 1970년대 삶의 질이라는 관점에서 빈곤을 보 다 넓게 정의하려는 일련의 시도가 있었고, 오 늘날 $\mathrm{OECD/DAC}$, World Bank에서는 빈곤을 소득 외 여러 잣대로 정의내리고 있음.
- 2001년 발표된 DAC 빈곤감소 가이드라인에 따르면 빈곤을 총 5 가지 능력의 부재로 간주 하고 있는데 1) 경제력(소득 획득 능력) 2) 인 간적 삶(보건, 식자, 숙소, 적절한 영양상태, 깨끗한 식음수) 3) 정치적 자유(기본적인 인권 및 정치적 자유) 4) 사회문화적 자유(사회적 지위, 지역사회에 참여할 수 있는 능력) 5) 방 어권(경제적 혹은 또다른 외부 충격을 감수할 능력)이 그것임.

- 따라서 $\mathrm{IPPF}$ 는 빈곤을 경제력보다는 선택의 부재로 정의하는 것이 옳다고 여김. 즉 양질의 교육, 보건 서비스, 생식, 출산 등 삶의 여러 측면에서 선택의 자유를 누릴 수 없다면 이는 빈곤한 상황이라고 간주해야 함. 따라서 남녀 노소가 SRHR를 온전히 누릴 수 없는 상황에 서는 빈곤척결은 불가능할 수밖에 없음.

[ 자료 : 주영국대사관 ] 